\title{
Uji Antimikroba Fraksi Ekstrak Metanol, Etil Asetat dan $n$-Heksana Daun Tabar-Tabar (Costus speciosus) dan Toksisitasnya Terhadap Larva Udang
}

\author{
Antimicobial Test of Fraction of Methanol, Ethyl Acetate and $\boldsymbol{n}$-Hexane Extract of Tabar- \\ Tabar (Costus speciosus) Leaf and Their Toxicity to Brine-Shrimp Larvae
}

\author{
Dwi Suryanto*, Tata B Kelana, dan Sri Wahyuni \\ Departemen Biologi, Fakultas MIPA, Universitas Sumatera Utara \\ Jl. Bioteknologi No. 1, Medan 20155 \\ E-mail:d.suryanto@lycos.com*Penulis untuk korespondensi
}

\begin{abstract}
A Study on antimicrobial examination of fractions of methanol, ethyl-acetate, and $\boldsymbol{n}$-hexane extract of tabar-tabar (Costus speciosus) leaf to bacteria (Bacillus sp., Staphylococcus aureus, Escherichia coli, and Serratia marcescens) and yeast (Candida albicans), and their toxicity to brine-shrimp (Artemia salina) larvae has been done. Examination of antimicrobial activities to the microbes were done by agar diffusion method, while test for toxicity was done by exposing 2 days-old larvae to certain concentration of the extract. Preliminary tests on phytochemical compounds in leaf were done by Mayer's, $\mathrm{FeCl}_{3}, \mathrm{Mg}-\mathrm{HCl}$, foam, and $10 \% \mathrm{NaOH}$ in methanol tests. The results showed that methanol leaf extract of tabar-tabar in general inhibited more in the growth of gram-positive Bacillus sp. and $S$. aureus rather than to other tested microbes. Compared to methanol and ethyl-acetate fraction, $n$-hexane fraction of the leaf inhibited more Bacillus sp. and $E$. coli. Interestingly, $C$. albicans was highly inhibited by $n$-hexane fractions. $\mathrm{LC}_{50}$ of methanol extract, ethyl-acetate, and $n$-hexane fraction, were 45.53, 478.37, and 824.20 ppm, respectively. Preliminary test on phytochemical compounds showed saponin was only detected in fractions of methanol and ethyl acetate extracts, steroid was detected in fraction of methanol, while triterpenoid was detected in fraction of $\boldsymbol{n}$-hexane extract. Phenolic was detected in all extract fractions, while flavonoid, kumarin, and alkaloid on the other hand were not detected.
\end{abstract}

Key words: Costus speciosus, antimicrobial activity, brine-shrimp, toxicity

Abstrak

Telah dilakukan kajian sifat antimokroba fraksi ekstrak methanol, etil-asetat dan $\boldsymbol{n}$-heksana daun tabar-tabar (Costus spesiosus) terhadap bakteri (Bacillus sp., Staphylococcus aureus, Escherichia coli, and Serratia marcescens) dan kamir (Candida albicans), serta toksisitasnya terhadap larva udang (Artemia salina). Uji aktivitas antimikroba dilakukan dengan menggunakan metode difusi agar, sedangkan uji toksisitas dilakukan dengan memapar larva udang umur 2 hari pada konsentrasi tertentu ekstrak. Uji pendahuluan fitokimia daun menggunakan uji Meyer's, $\mathrm{FeCl}_{3}, \mathrm{Mg}-\mathrm{HCl}$, busa, dan $10 \% \mathrm{NaOH}$ dalam metanol. Hasil menunjukkan secara umum ekstrak metanol daun tabar-tabar lebih menghambat pertumbuhan bakteri gram-positif Bacillus sp. and S. aureus daripada mikroba uji lainnya. Jika dibandingkan dengan fraksi metanol dan etil-asetat, fraksi $n$-heksana lebih menghambat Bacillus sp. dan $E$. coli. Fraksi $n$-heksana lebih menunjukkan daya hambatnya terhadap $\boldsymbol{C}$. albicans. LC $_{50}$ ektrak methanol, etil-asetat, dan n-heksana berturut-turut adalah 45,53; 478,37; dan 824,20 ppm. Uji pendahuluan fitokimia menunjukkan bahwa saponin hanya terdeteksi pada fraksi metanol dan etil-asetat, steroid terdeteksi pada fraksi metanol, sedangkan triterpenoid terdeteksi pada fraksi $\boldsymbol{n}$-heksana. Fenolat terdeteksi di semua fraksi, sedangkan flavonoid dan alkaloid tidak terdeteksi.

Kata kunci: Costus speciosus, aktivitas antimikroba, larva udang, toksisitas 


\section{Pendahuluan}

Pengobatan dan pendayagunaan obat tradisional merupakan salah satu bagian dari program pelayanan kesehatan dasar, serta merupakan suatu alternatif untuk memenuhi kebutuhan dasar di bidang kesehatan. Obatobatan yang berasal dari tumbuhan telah digunakan sejak lama untuk menjaga kesehatan dan menyembuhkan penyakit. Sangat banyak catatan tentang penyiapan obat-obatan tradisional ini di masyarakat (Maiti et al., 2006). Di negara berkembang, diperkirakan sekitar $80 \%$ populasi bergantung pada obat-obatan tradisional untuk menjaga kesehatan (Kumar et al., 2006). Obat-obatan ini penting karena dianggap tidak memberikan efek samping. Saat ini, penelitian difokuskan pada pemanfaatan tumbuhan obat dalam berbagai sistem tradisional (Idu et al., 2006).

Agar peranan obat tradisional, khususnya tumbuhan obat dalam pelayanan kesehatan dapat ditingkatkan, perlu didorong upaya pengenalan, penelitian, pengujian, dan pengembangan khasiat dan keamanan suatu tumbuhan. Tumbuhan obat dalam beberapa puluh tahun terakhir menjadi objek penelitian farmakologi yang sangat intensif (Kumar et al., 2006). Selama 5 tahun terakhir lebih dari 13.000 jenis tumbuhan dipelajari untuk kemungkinan digunakan sebagai obat (Kumar et al., 2006). Oleh karena itu, merupakan hal yang menarik dapat melakukan penapisan tumbuhan obat pada masyarakat tradisional untuk memvalidasi penggunaannya di masyarakat dan untuk memperoleh bahan aktif yang dapat digunakan sebagai obat untuk meningkatkan kualitas perawatan kesehatan (Gurav et al., 2008; Kianbakht dan Jahaniani, 2003).

Salah satu tumbuhan yang digunakan sebagai obat tradisonal yaitu tabar-tabar (Costus speciosus (Koen) J. E Smith; Familia Zingiberaceae). Tumbuhan ini oleh masyarakat Karo yang tinggal di sekitar kawasan Taman Nasional Gunung Leuser (TNGL) Kabupaten Langkat digunakan sebagai obat batuk (Mumpuni, 2004). Saat ini, resistensi ganda mikroba penyebab penyakit pada manusia, hewan, dan tumbuhan meningkat terhadap obat antibiotika karena penggunaan yang antibiotika yang sembarangan. Keadaan ini memaksa para ahli mencari senyawa antimikroba baru dari berbagai sumber seperti tumbuhan obat (Essawi dan Srour, 2000; Kumar et al., 2006; Gurav et al., 2008).

Penelitian ini bertujuan untuk mengetahui bioaktivitas ekstrak metanol, ekstrak hasil fraksinasi etil asetat dan $n$-heksana dengan melakukan uji aktivitas antimikroba, uji toksisitas dengan larva udang Artemia salina, dan uji pendahuluan fitokimia untuk mengetahui kandungan senyawa metabolit sekunder dalam ekstrak daun tabar-tabar.

\section{Metode Penelitian}

\section{Pengambilan dan Pengeringan Contoh Tumbuhan}

Contoh daun tumbuhan tabar-tabar diambil dari hutan TNGL Tangkahan, Kabupaten Langkat, Sumatera Utara. Contoh daun segar dibawa ke laboratorium, dicuci bersih dan dipotong kecil-kecil agar mudah dikeringkan. Contoh kemudian dibiarkan mengering selama 1 minggu.

\section{Pembuatan Ekstrak Fraksi Metanol, Etil Asetat, dan $\boldsymbol{n}$-Heksana}

Contoh daun kering dimaserasi dengan metanol dalam botol dan dibiarkan selama 5 hari. Pengadukan dilakukan setiap hari. Campuran tersebut kemudian diserkai dan disaring untuk mendapatkan maserat. Maserat diuapkan dengan menggunakan rotavapor. Ekstrak kental yang diperoleh dimasukkan ke dalam botol vial steril dan dilanjutkan dengan proses pengeringan menggunakan desikator. Pengujian aktivitas antimikroba larutan ekstrak dilakukan pada konsentrasi (g/v) 1\%, 5\%, 10\%, $15 \%$, dan $20 \%$ dengan pelarut DMSO.

Sebagian ekstrak metanol difraksinasi berturut-turut dengan etil asetat $5 \times 500 \mathrm{ml}$ dan $n$-heksana $5 \times 500 \mathrm{ml}$. Tiap-tiap ekstrak fraksi yang diperoleh diuapkan dengan menggunakan alat rotavapor sampai kering. Ekstrak fraksi kemudian ditimbang untuk menentukan beratnya. Pengujian antimikroba dilakukan pada konsentrasi 100, 500, 1000, dan 2000 ppm dengan pelarut DMSO. 


\section{Uji Daya Hambat Pertumbuhan Mikroba}

Biakan-biakan bakteri uji yang digunakan (Escherichia coli, Serratia marcescens, Staphylococcus aureus, dan Bacillus sp.) dalam penelitian ini merupakan koleksi Laboratorium Mikrobiologi, Fakultas MIPA, USU, Medan. Biakan jamur yang dipakai (Candida albicans) diperoleh dari Laboratorium Mikrobiologi, Fakultas Kedokteran, USU, Medan.

Sebanyak 1-2 ose tiap-tiap biakan murni bakteri dan jamur uji yang telah dikultur disuspensikan dengan menggunakan larutan $\mathrm{NaCl} 0.85 \%$ sampai diperoleh kekeruhan $\approx$ $1 \times 10^{8} \mathrm{CFU} / \mathrm{ml}$. Suspensi biakan uji diusapkan secara merata dengan menggunakan kapas lidi steril pada permukaan media Nutrient Agar untuk bakteri dan media Potato Dextrose Agar untuk jamur uji dalam cawan petri. Biakan dibiarkan selama 15 menit.

Sebanyak 6 buah cakram kosong (Oxoid, Inggris) ditetesi masing-masing $10 \mu \mathrm{l}$ ekstrak atau ekstrak fraksi sesuai dengan konsentrasi uji. Cakram kemudian diletakkan pada suspensi sebaran biakan dalam cawan petri dengan menggunakan pinset steril sambil menekan sedikit pada permukaan media usapan agar menempel. Biakan lalu diinkubasi pada suhu $30^{\circ} \mathrm{C}$ selama 24 jam. Aktivitas antimikroba diukur sebagai diameter hambatan yang terbentuk setelah ekstrak berdifusi. Diameter hambatan diukur dengan menggunakan mistar antibacterial zone gauge for Kirby-Bauer methods of susceptibility testing dalam satuan mm (Cappuccino dan Sherman, 1983).

\section{Uji Toksisitas Ekstrak Terhadap Larva Udang A. salina}

Kista udang A. salina ditetaskan dalam bejana yang sudah diisi air laut. Bejana terbagi dua bagian yang saling berhubungan, dengan bagian terang dan bagian gelap. Bejana dilengkapi dengan alat aerasi. Kista dimasukkan ke dalam bagian yang gelap dan dibiarkan menetas. Setelah 48 jam hewan uji siap untuk digunakan (Kelana, 2003).

Larutan uji disiapkan dengan konsentrasi akhir dalam air laut sebesar 10 ppm, 100 ppm, dan 1000 ppm dengan pelarut DMSO. Larutan kontrol digunakan DMSO tanpa penambahan ekstrak. Setiap konsentrasi dibuat ulangan sebanyak 3 kali (3 vial). Ke dalam setiap vial ditambahkan DMSO sebanyak $50 \quad \mu l$ dan ditambahkan air laut kurang lebih $2 \mathrm{ml}$. Sebanyak 10 ekor larva udang dimasukkan ke dalam vial. Volume dicukupkan sampai $5 \mathrm{ml}$ dengan air laut. Kematian larva udang diamati setelah 24 jam. Data yang diperoleh diolah dengan menggunakan program Finney untuk menentukan LC Lo $_{50}$ (Kelana, 2003).

\section{Uji Pendahuluan Fitokimia}

Untuk mengetahui keberadaan alkaloida, fenolik, kumarin, flavanoid, saponin, steroid, dan triterpenoid dalam ekstrak metanol, fraksi etil asetat dan fraksi $n$-heksana dilakukan uji dengan menggunakan beberapa pereaksi, antara lain: Mayer, $\mathrm{FeCl}_{3}, 10 \% \mathrm{NaOH}$, metanol, dan $\mathrm{Mg}$ $\mathrm{HCl}$.

\section{Hasil dan Pembahasan}

\section{Uji Daya Hambat Pertumbuhan Mikroba}

Uji daya hambat ekstrak daun tabar-tabar terhadap pertumbuhan bakteri dan jamur menunjukkan bahwa ekstrak daun ini memiliki aktivitas antimikroba yang berbeda. Hal ini dapat terlihat dengan terbentuknya zona bening yang bervariasi ukurannya di sekitar wilayah cakram. Terbentuknya zona bening tersebut disebabkan bahan antimikroba yaitu ekstrak metanol daun tabar-tabar mengalami perembesan ke daerah sekitarnya sehingga pertumbuhan bakteri dan jamur terhambat.

Kemampuan antimikroba ekstrak metanol, dan fraksi etil asetat dan $n$-heksana daun tabartabar dalam menghambat pertumbuhan $S$. aureus, Bacillus sp., S. marcescens, E. coli dan jamur C. albicans terlihat berbeda (Gambar 1-3). Karena menggunakan pelarut yang berbeda, jumlah kandungan senyawa altif dari tiap-tiap ekstrak boleh jadi berbeda sehingga memberikan efek penghambatan pertumbuhan yang berbeda. Di samping itu kepekaan setiap jenis sel mikroba uji berbeda. Kepekaan ini bisa disebabkan oleh perbedaan bahan penyusun dinding atau membran sel.

Luasnya wilayah hambatan merupakan indikator untuk kepekaan mikroba terhadap suatu zat aktif. Peningkatan konsentrasi menunjukkan peningkatan daya hambat 
pertumbuhan mikroba uji. Berdasarkan pengukuran diameter zona hambat, ekstrak metanol mampu menghambat pertumbuhan Bacillus sp. dan S. aureus, sedikit efektif pada $E$. coli dan hampir tidak ada pengaruhnya terhadap $S$. marcescens dan jamur C. albicans (Gambar 1). Hasil uji kemampuan menghambat ekstrak fraksi etil asetat terhadap mikroba uji menunjukkan bahwa ekstrak fraksi ini mampu menghambat pertumbuhan mikroba uji dengan hasil yang bervariasi. Penghambatan yang dihasilkan oleh ekstrak fraksi etil asetat terbesar terjadi pada $S$. aureus, diikuti penghambatan terhadap S. marcescens dan E. coli. Daya hambat fraksi terhadap Bacillus sp. dan $C$. albicans kurang lebih sama (Gambar 2). Ekstrak fraksi etil asetat daun tabar-tabar dalam konsentrasi terendah (100 ppm) sudah mampu menghambat pertumbuhan mikroba uji. Peningkatan konsentrasi ekstrak fraksi ini juga menunjukkan peningkatan daya hambat pertumbuhan mikroba uji.

Hasil uji antimikroba ekstrak fraksi $n$ heksana menunjukkan bahwa ekstrak fraksi ini mampu menghambat pertumbuhan mikroba uji dengan hasil yang bervariasi. E. coli, Bacillus sp. dan C. albicans dapat dihambat meskipun lebih kecil daripada daya hambat ekstrak fraksi ini terhadap pertumbuhan $S$. marcescens dan $S$. aureus (Gambar 3). Meski demikian secara keseluruhan ekstrak fraksi ini lebih menghambat pertumbuhan mikroba uji dibandingkan dengan ekstrak etil asetat. Sangat menarik, daya hambat terhadap pertumbuhan $C$. albicans pada fraksi $n$ heksana sangat besar. Daya hambat pertumbuhan terhadap Bacillus sp. dan E. coli juga terlihat lebih besar dibandingkan dengan hal yang sama pada ekstrak metanol dan ekstrak fraksi etil asetat.

Pengujian ekstrak fraksi $n$-heksana daun tabar-tabar menunjukkan bahwa semakin besar konsentrasi yang digunakan semakin besar zona hambat yang terbentuk. Akumulasi senyawa pada konsentrasi yang lebih tinggi menimbulkan daya efektif yang lebih tinggi pula. Ekstrak fraksi $n$-heksana daun tabar-tabar dalam konsentrasi terendah (100 ppm) juga mampu menghambat pertumbuhan mikroba uji.

Peningkatan konsentrasi ekstrak berpengaruh terhadap kemampuan daya hambat yang makin besar. Dengan makin terakumulasinya ekstrak yang bersifat antimikroba dari tumbuhan tabar-tabar pada media tumbuh makin mengganggu proses pertumbuhan mikroba uji. Terbentuknya zona hambat sangat tergantung oleh jumlah bahan antimikroba yang diteteskan ke cakram, daya larut antimikroba tersebut ke media, koefisien difusi, dan efektifnya antimikroba tersebut (Madigan et al., 2003). Kemampuan menghambat pertumbuhan bakteri dan jamur diindikasikan melalui penggunaan tumbuhan ini sebagai obat batuk (Mumpuni, 2004), obat disentri, dan obat radang selaput lendir mata (Wahyuningsih, 2007). Jahe, tumbuhan sekerabat dengan tabar-tabar memberikan efek penghambatan terutama pada bakteri grampositif seperti B. cereus (Alzoreky dan Nakahara, 2002).

Kemampuan bahan antimikroba dalam menghambat pertumbuhan mikroba dipengaruhi oleh zat aktif dalam ekstrak yang dicobakan. Dari pengujian yang dilakukan terlihat adanya perbedaan kemampuan ekstrak metanol, ekstrak fraksi etil asetat, dan ekstrak fraksi $n$-heksana dalam menghambat pertumbuhan mikroba uji. Hal ini mengindikasikan adanya perbedaan senyawa yang terkandung dalam tiap-tiap ekstrak. Saponin tidak terdeteksi pada ekstrak fraksi $n$-heksana, sedang triterpenoid tidak terdeteksi pada ekstrak fraksi metanol dan $n$ heksana. Hadirnya triterpenoid pada fraksi $n$ heksana boleh jadi menyebabkan lebih besarnya zona hambat ekstrak $n$-heksana terhadap semua mikroba uji dibandingkan dengan ekstrak metanol dan etil asetat. Senyawa ini juga terlihat menghambat lebih besar pada jamur $C$. albicans dibandingkan dengan mikroba uji lain yang merupakan kelompok bakteri. 


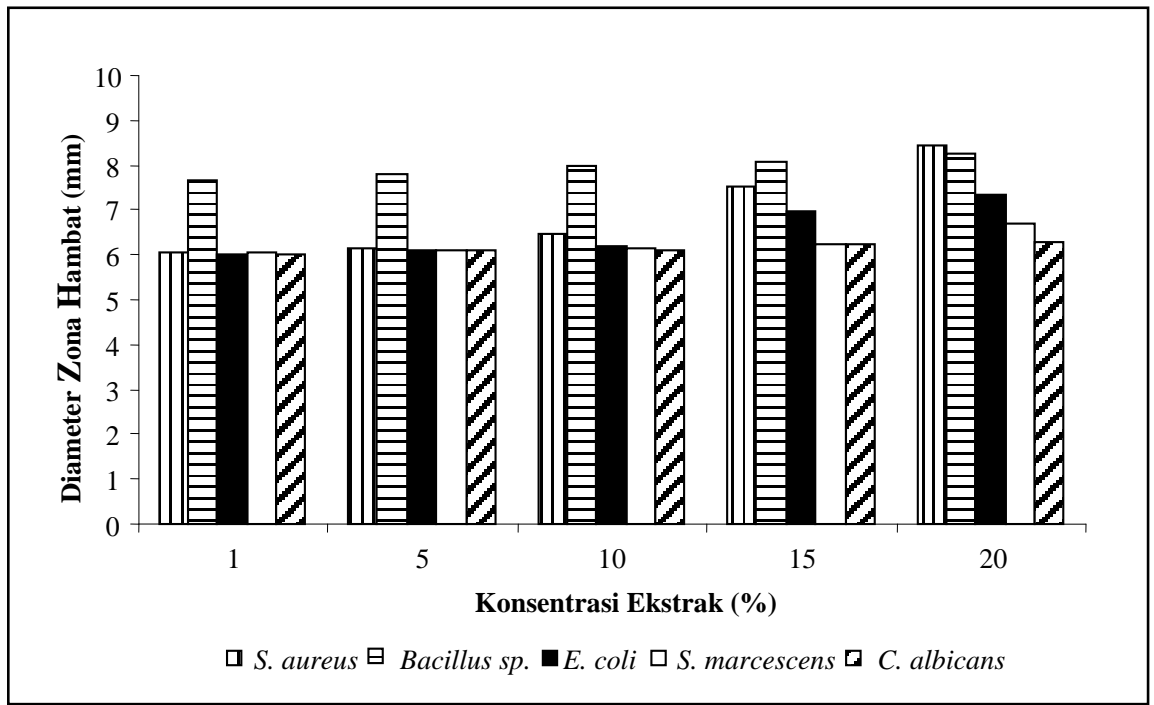

Gambar 1. Diameter zona hambat ekstrak metanol daun tabar-tabar.

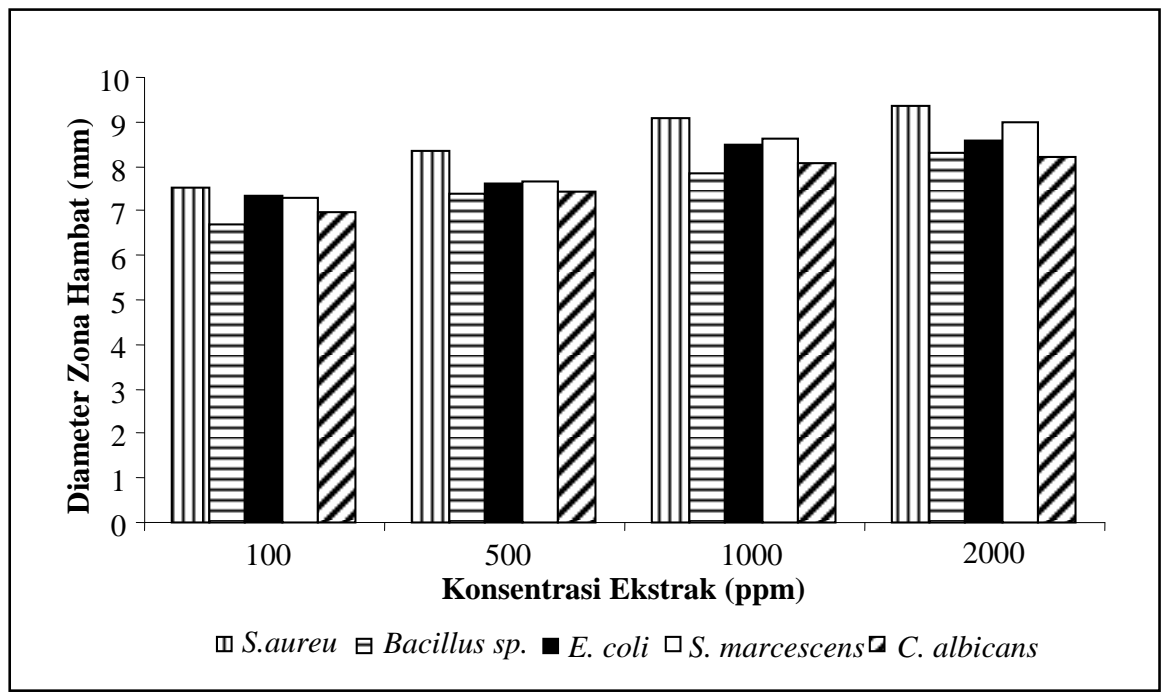

Gambar 2. Diameter zona hambat ekstrak fraksi etil asetat daun tabar-tabar.

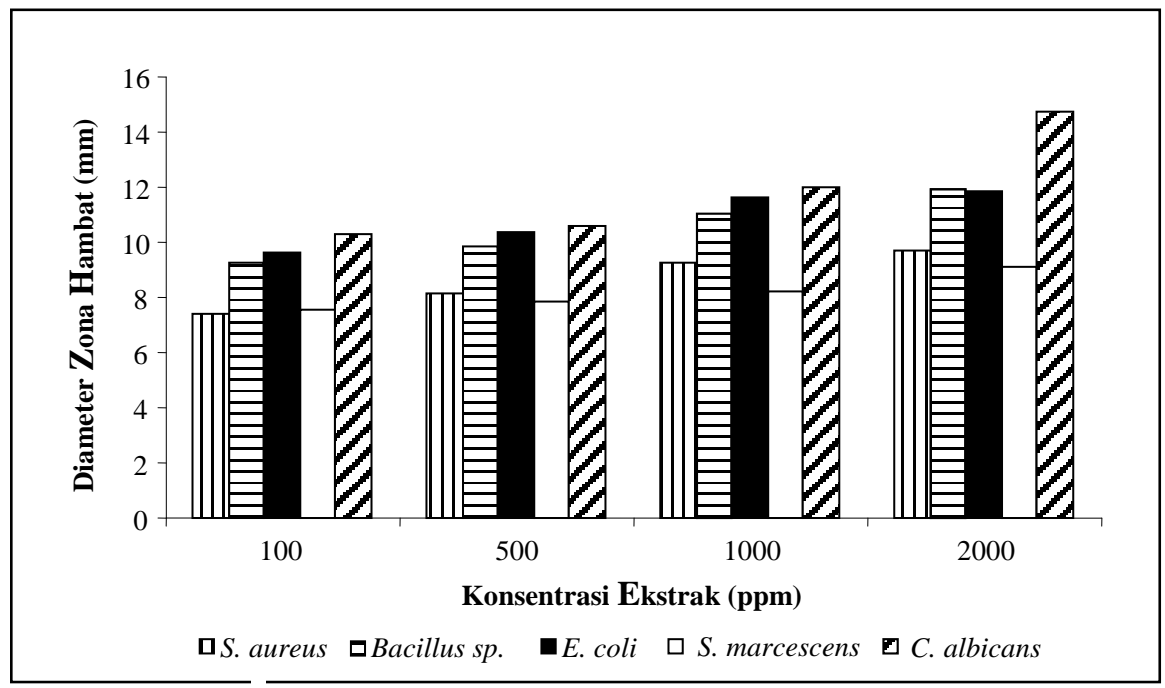

Gambar 3. Diameter zona hambat ekstrak fraksi $n$-heksana daun tabar-tabar. 


\section{Uji Toksisitas Ekstrak Terhadap Larva Udang A. salina}

Pengujian toksisitas dilakukan untuk mengetahui tingkat toksisitas terhadap organisme uji yang dapat memberikan gambaran awal terhadap penggunaan tabar-tabar sebagai obat. Hasil uji toksisitas ekstrak metanol, ekstrak fraksi etil asetat, dan ekstrak fraksi $n$-heksana daun tabar-tabar terhadap larva udang ditunjukkan pada Tabel 1. Peningkatan konsentrasi diikuti dengan peningkatan jumlah larva yang mati.

Hasil uji toksisitas tiap-tiap ekstrak menunjukkan $\mathrm{LC}_{50}$ yang berbeda. Toksisitas terhadap larva udang $A$. salina yang tertinggi berturut-turut ditunjukkan oleh ekstrak metanol, ekstrak fraksi etil asetat, dan ekstrak fraksi $n$ heksana dengan nilai $\mathrm{LC}_{50}$ berturut-turut sebesar 45.53, 478.37, dan 824.20 ppm. Hal ini mengindikasikan jumlah dan jenis senyawa yang ada dalan ekstrak berbeda sehingga memberikan efek toksik yang berbeda pula. Pertumbuhan sel yang cepat pada larva udang A. salina menyebabkan uji ini biasanya digunakan sebagai uji pendugaan awal atas kemampuan suatu senyawa menghambat pertumbuhan sel. Penghambatan petumbuhan sel berakibat pada kematian larva. Uji toksisitas ini merupakan uji yang dapat dilakukan dengan cepat, mudah, murah, tidak membutuhkan kondisi aseptis, dan menghasilkan hasil yang cukup baik (Collegate dan Molyneux, 1993).

\section{Uji Pendahuluan Fitokimia}

Hasil pemeriksaan pendahuluan kandungan metabolit sekunder daun tabar-tabar memperlihatkan adanya kandungan senyawa fenolik dalam ekstrak fraksi metanol, etil asetat, dan $n$-heksana. Saponin terdapat pada ekstrak fraksi metanol dan etil asetat, flavonoida terdapat pada ekstrak fraksi etil asetat, dan triterpenoid terdapat pada ekstrak fraksi $n$ heksana. Uji metabolit sekunder lainnya seperti alkaloida, flavonoida, dan kumarin menunjukkan bahwa senyawa ini tidak terdeteksi pada uji pendahuluan (Tabel 2). Polaritas pelarut yang digunakan memengaruhi hasil senyawa yang terlarut.

Wahyuningsih (2007) menyebutkan bahwa daun dan batang tabar-tabar mengandung saponin, flavanoida dan tanin, sedang bunga mengandung saponin, flavonoida dan senyawa senyawa polifenol. Telaah lain menyebutkan bahwa tumbuhan ini mengandung saponin, glikosida sianogenik, tanin, flavomoida, dan karbohidrat (Anaga et al., 2004). Telaah yang dilakukan terhadap kerabat dekat tumbuhan ini, C. spiralis menunjukkan keberadaan sterol dan glikosida furostanol (Willuhn dan Pretzsch, 1985) dan glikosida flavonol (Antunes et al., 2000).

Tabel 1. Jumlah kematian larva udang dalam uji toksisitas ekstrak metanol, ekstrak fraksi etil asetat, dan ekstrak fraksi $n$-heksana daun tabar-tabar.

\begin{tabular}{|c|c|c|c|c|c|}
\hline \multirow[t]{2}{*}{ Fraksi } & \multicolumn{4}{|c|}{ Konsentrasi (ppm) } & \multirow[t]{2}{*}{$\mathrm{LC}_{50}(\mathrm{ppm})$} \\
\hline & 1 & 10 & 100 & 1000 & \\
\hline Metanol & 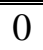 & 2 & 6,33 & 10 & 45,53 \\
\hline Etil asetat & 2 & 2 & 4 & 5,67 & 478,37 \\
\hline$n$-heksana & 1 & 2 & 3 & 5,33 & 824,20 \\
\hline
\end{tabular}

Tabel 2. Kandungan beberapa senyawa metabolit sekunder dalam ekstrak fraksi metanol, etil asetat, dan $n$-heksana daun tabar-tabar.

\begin{tabular}{lccc}
\hline \hline \multicolumn{1}{c}{ Golongan Senyawa } & \multicolumn{3}{c}{ Fraksi } \\
\cline { 2 - 4 } & Metanol & Etil Asetat & $\boldsymbol{n}$-Heksana \\
\hline \hline Fenolik & + & + & + \\
Saponin & + & + & - \\
Flavonoida & - & + & - \\
Kumarin & - & - & - \\
Alkaloida & - & - & - \\
Steroid & - & - & + \\
Triterpenoid & - & - & \\
\hline \hline
\end{tabular}




\section{Simpulan dan Saran}

\section{Simpulan}

Dari hasil penelitian dapat disimpulkan bahwa ekstrak metanol daun tabar-tabar lebih menghambat bakteri gram positif dibandingkan dengan bakteri gram negatif, sedangkan fraksi $n$ heksana menghambat kelompok baik bakteri gram negatif maupun gram positif, bahkan lebih menghambat pertumbuhan jamur. Pengujian pada larva udang $\left(\mathrm{LC}_{50}\right)$ menunjukkan bahwa efek toksik tertinggi berturut-turut terdapat pada ekstrak methanol, fraksi etil-asetat, dan $n$ heksana. Uji pendahuluan fitokimia menunjukkan saponin hanya terdapat pada ekstrak metanol dan etil-asetat, steroid terdapat pada ekstrak metanol, sedangkan triterpenoida terdapat pada fraksi n-heksana.

\section{Saran}

Pemurnian senyawa aktif diperlukan untuk menentukan struktur senyawa dan aktivitas antimikroba serta toksisitas terhadap sel hewan tingkat tinggi.

\section{Ucapan Terima Kasih}

Artikel ini didedikasikan untuk rekan kami alm. Drs. Tata Bintara Kelana, M.Si.

\section{Daftar Pustaka}

Ahmad, S.A. 1990. Phyto Medica. Majalah Ilmu-Ilmu Penopang Obat Bahan Alam. Yayasan Pengembangan Obat Bahan Alam Phyto Medica, Jakarta.

Alzoreky, N.S. dan Nakahara, K. 2003. Antibacterial Activity of Extracts from Some Edible Plants commonly Consumed in Asia. Int. J. Food Microbiol, 80: 223-230.

Anaga, A.O., Njoku, C.J., Ekejiuba, E.S., Esiaka, M.N. dan Asuzu, I.U. 2004. Investigations of the Methanolic Leaf Extract of Costus afer. Ker for Pharmacological Activities in vitro and in vivo. Phytomedica, 11: 242-248.

Anonim. 2007. Costus speciosus. http://www. doctorgarma.com/rst/ru-rta. 04/26/2007.

Antunes, A.S., da Silva, B.P. dan Parente, J.P. 2000. Quantitative Determination of
Monosaccharides as Flavonol Glycosides from Costus spiralis. Fitoterapia, 71: 507-510.

Cappucino, J.G. dan Sherman, N. 1983. Microbiology a Laboratory Manual. Addison-Wesley Publishing Co. 81-83, 371-377.

Culvenor, C.C.J. dan Fitzgerald, J.S. 1963. A Field Method for Alcaloid Screening of Plants. J. Pharm. Sci, 52: 303-304.

Essawi, T. dan Srour, M. 2000. Screening of Some Palestinian Medicinal Plants for Antibacterial Activity. J. Ethnopharmacol, 70: 343-349.

Feigl, F. 1960. Spot Test in Organic Analysis. $8^{\text {ed }}$. Elseiver Publishing Co. Japan.

Gurav, S.S., Gulkari, V.D., Duragkar, N.J. dan Patil, A.T. 2008. Antimicrobial Activity of Butea monosperma Lam. Gum. IJPT, 7: 21-24.

Harborne, J.B. 1987. Metode Fitokimia. Terbitan Kedua. Institut Teknologi Bandung, Bandung.

Hembing, W.K., Setiawan, D., Agustinus, S.W., Thomas, Y. dan Bambang, W. 1994. Tumbuhan Obat Berkhasiat di Indonesia. Edisi kedua. Penerbit Pustaka Kartini, Jakarta.

Idu M., Omogbai, E.K.I., Amaechina, F.C. dan Ataman, J.E. 2006. Some Cardiovascular Effects of Aqueous Extract of the Leaves of Stachytapheta jamaiciens (L) Vahl. Int J. Pharmacol, 2: 163-165.

Jaiswal, A.K., Sail, K.B. dan Satya, B.A. 1994. Anxiotik Activity of Azadirachta indica Leaf Ekstrak in Rats. Indian J. Exp. Biol, 31: 47-56.

Kelana, T.B. 2003. Isolasi, Elusidasi Struktur dan Uji "Brine Shrimp" Kandungan Kimia Utama Daun Ficus deltoideus Jack. Var. bilobata. Tesis. Program Pasca Sarjana, Universitas Andalas, Padang.

Kianbakht, S. dan Jahaniani, F. 2003. Evaluation of Antibacterial Activity of Tribulus terrestris L. Growing in Iran. IJPT, 2: 22-24.

Kumar, R.S., Sivakumar, T., Sundaram, R.S., Sivakumar, P., Nethaji, R., Gupta, M. dan Mazumdar, U.K. 2006. Antimicrobial and Antioxidant Activities of Careya arborea Roxb. Stem Bark. IJPT, 5: 35-41.

Maiti, A., Dewanjee, S., Mandal S.C. dan Annadurai, S. 2007. Exploration of Antimicrobial Potential of Methanol and Water Extract of Seeds of Swietenia macrophylla (Family: Meliaceae), to Substantiate Folklore Claim. IJPT, 6: 99-102.

Mumpuni, M. 2004. Inventarisasi Tumbuhan Obat Di Kawasan Hutan Tangkahan Taman Nasional Gunung Leuser Kabupaten Langkat. Skripsi. Fakultas MIPA Universitas Sumatera Utara, Medan. 
Mursito, B. 2002. Ramuan Tradisional untuk Pengobatan Jantung. Penebar Swadaya, Jakarta.

Owolabi, O.J. dan Nworgu, Z.A.M. 2009. Antiinflammatory and Anti Nociceptive Activities of Costus lucanusianus (Costaceae). Pharmacologyonline, 1: 1230-1238.

Sardjono, O. 1989. Penggunaan Obat Tradisional Secara Rasional. Penerbit Majalah Cermin Dunia Kedokteran. Jakarta.

Siswanto, W.Y. 2004. Penanganan Hasil Panen Tumbuhan Obat Komersial. Edisi Revisi. Penebar Swadaya, Jakarta.
Steenis, C.G.G.J. 2003. Flora Untuk Sekolah di Indonesia. Cetakan Kesembilan. PT Pradnya Paramita, Jakarta.

Tampubolon, O.T. 1995. Tumbuhan Obat Bagi Pecinta Alam. Cetakan kedua. Bhratara, Jakarta.

Wahyuningsih, E. 2007. Costus speciosus (Koenig) J.E Smith. Pusat Penelitian dan Pengembangan Tumbuhan Obat UNAS/ P3TO UNAS. http://iptek.apjii.or.id/artikel/ttg_tumbuhan_oba t/unas/Pacing.pdf. 04/26/2007.

Willuhn, G. dan Pretzsch, G. 1985. Diosgenin and Sterols from Costus spiralis. Planta Med, 3: 185-187. 